برررسى تأثير فشار بر گسيلندگى آب با روش كيت آبيارى قطرهاى بدون استفاده از يمب؛، در جهار نوع قطرهج

مرتضى خواست، موسى حسام”، ابوطالب هزارجريبى و اميد محمدى'

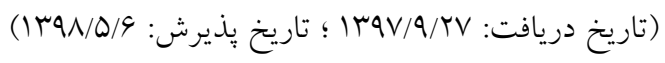

جكيده

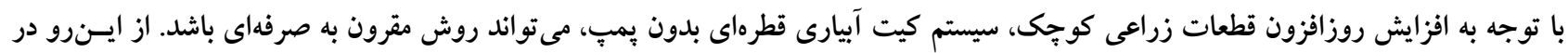

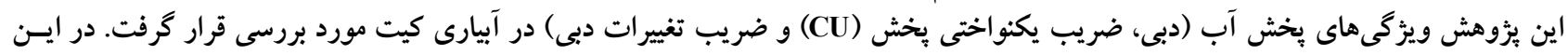

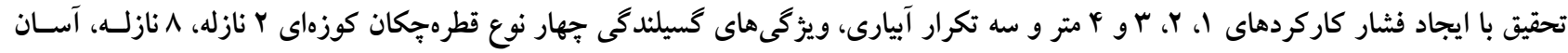

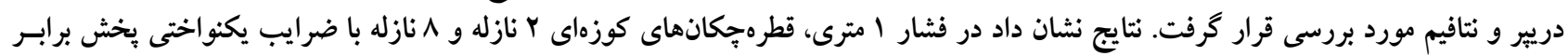

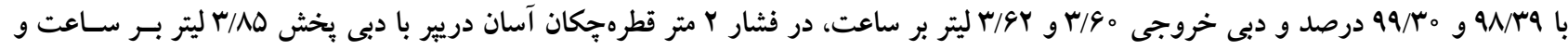

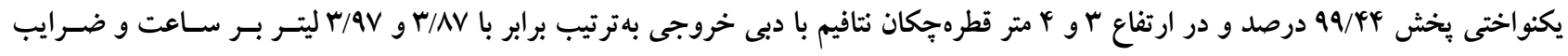

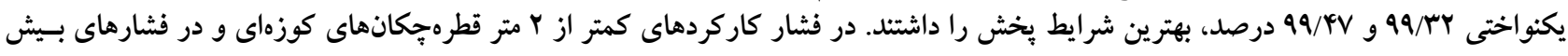

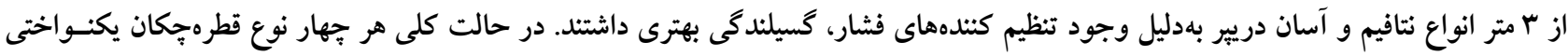
بخش و دبى مطلوبى را در فشارهاى مختلف ايجاد كردند.

وازههاى كليدى: كيت آبيارى، قطرهجكان، دبى، ضريب يكنواختى بِش 
و يورودريبٍ (Turbo Plus)

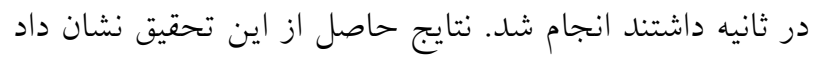

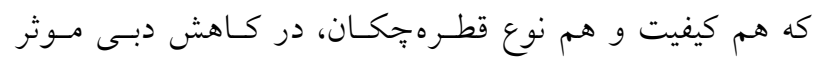

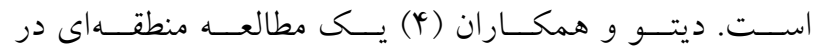

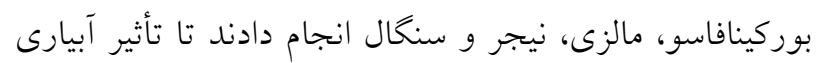

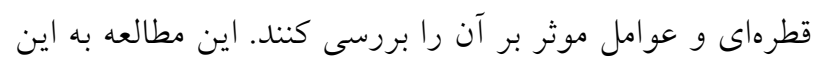

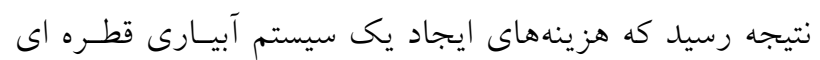

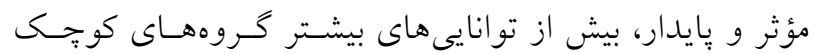

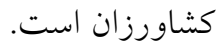
كيتهــاى آبيـارى (Irrigation Kitt)، سيستـمهــاى آبيـارى قطرهاى كمهزينه هستند، كه با كمترين ميزان فشار كاركرد، قابـل بهـرهبردارى هسـتند. كيـتهــاى آبيـارى بيشـتر بــراى آبيـارى سبزيجات و در بعضى موارد درختان ميوه در قطعههاى كوجى ئرى

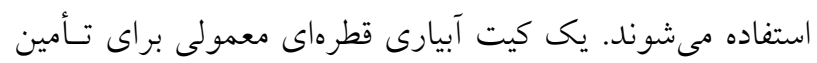

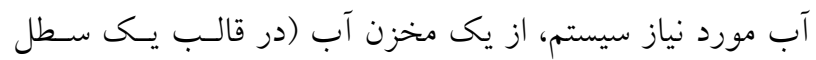

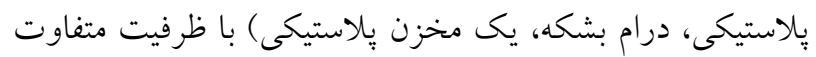

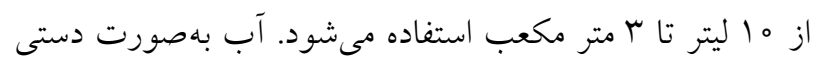

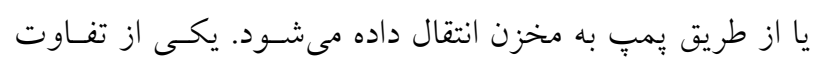

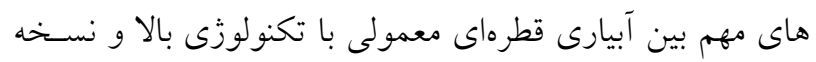

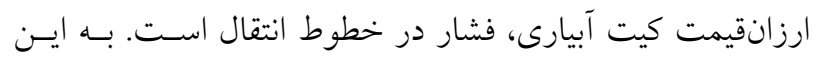

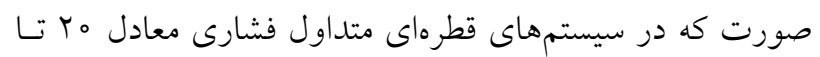

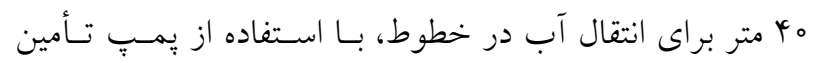

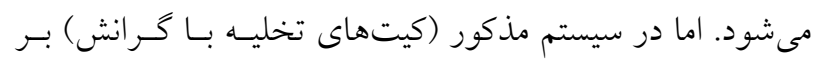

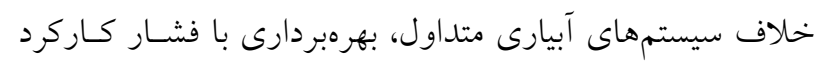

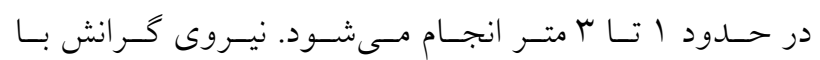

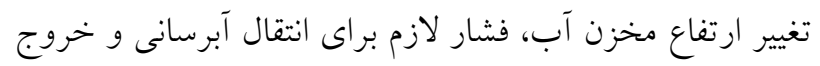

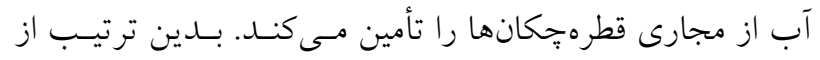

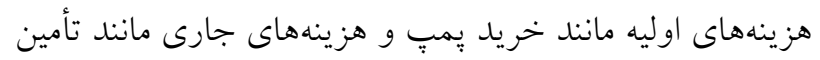

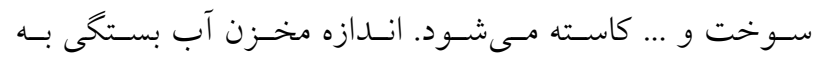
مساحت تحت يوشش كيت قطرهاى دارد (9 و 11). در تحليـل

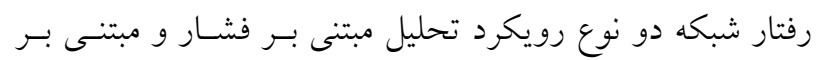

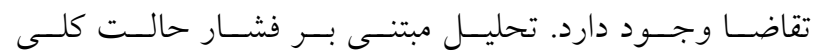

بهمنظور افـزايش ميـزان بهـرورى آب در بخـش كشـاورزى و

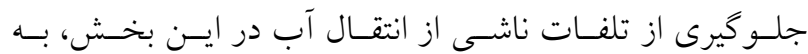

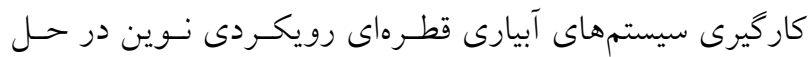

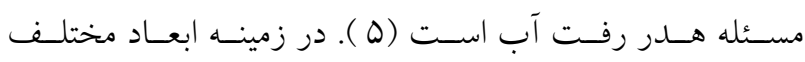

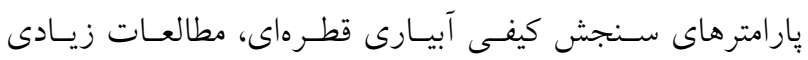

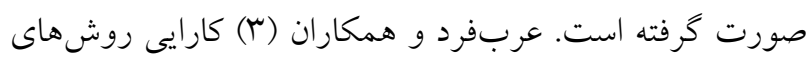

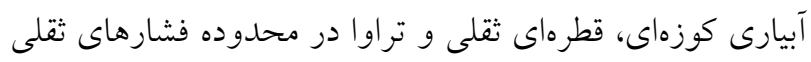

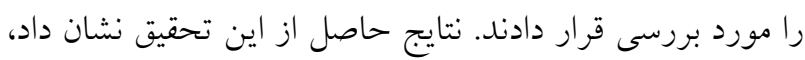

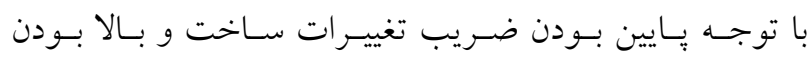

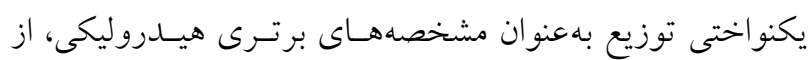

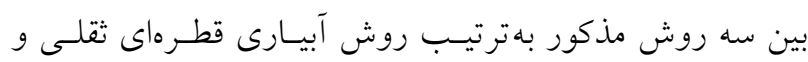
روش آبيارى كوزهاى (با اعمال فشار ثقلى) قابل توصيه هستـتند.

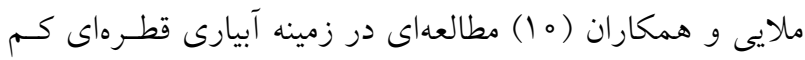
فشار بهصورت آزمايشخاهى انجام دادند. نتايج اين تحقيق نشان اندان

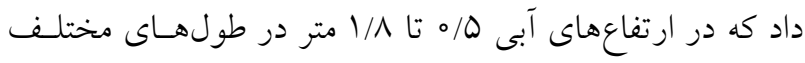

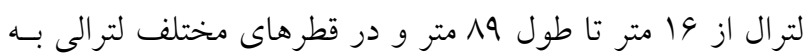

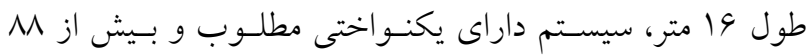
درصد حتى در كمترين ارتفاع آبى بود. همجنين نتـايج بـهـول

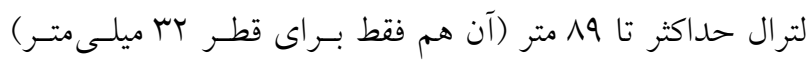

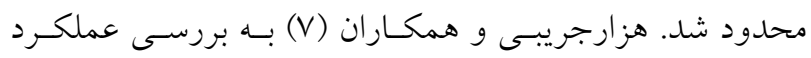

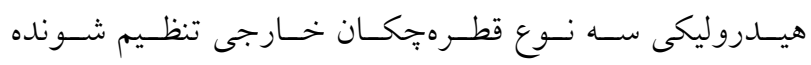

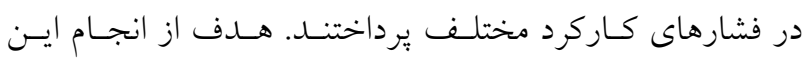

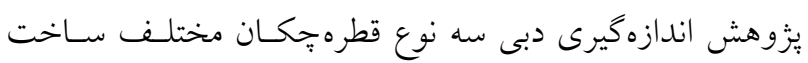

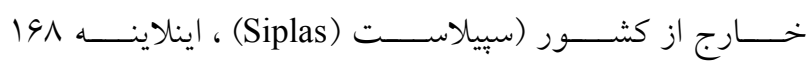

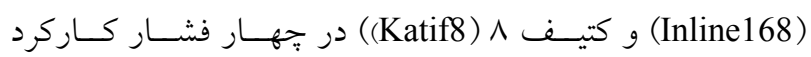
مختلف بود. نتايج اين تحقيق نشان داد هر سه نوع قطرهرجـان

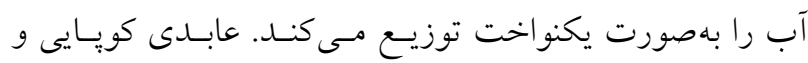

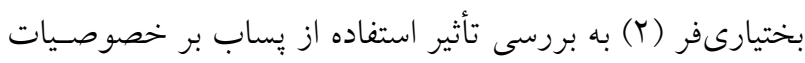

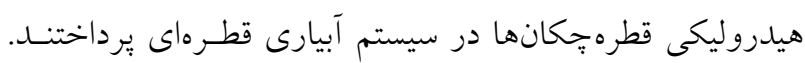

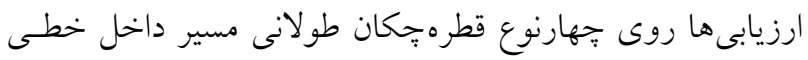

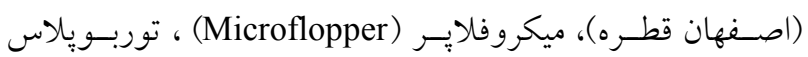




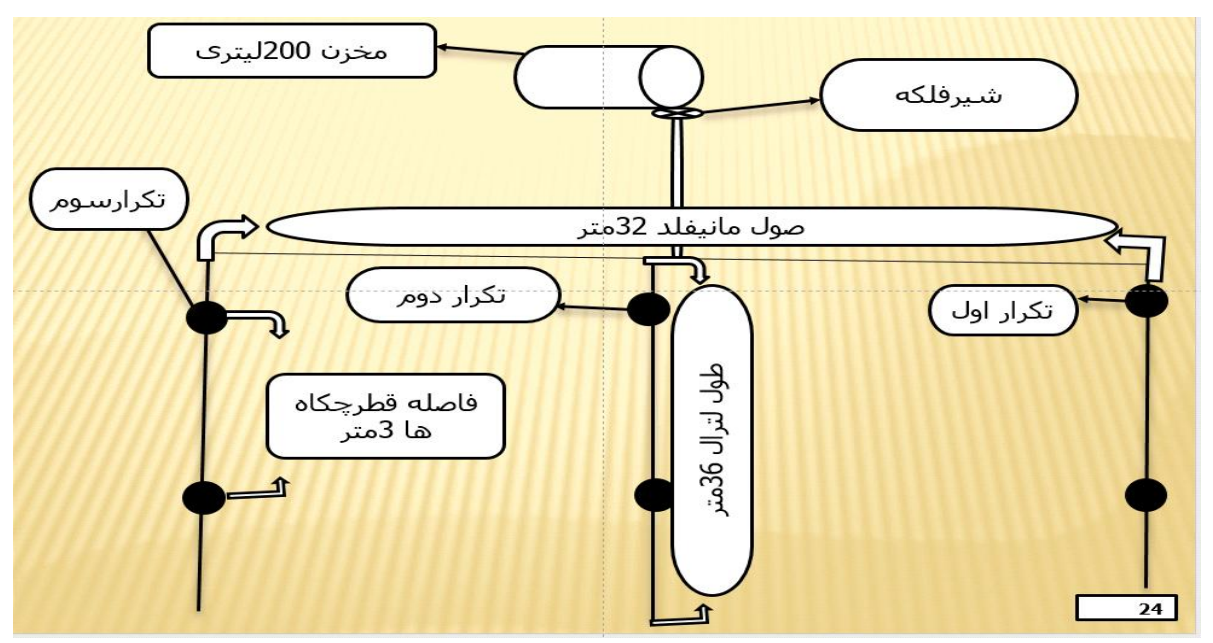

شكل ا. نمادين آرايش به كار گرفته شده در اين يُزوهش (كيت درام)

شود. هدف اصلى اين تحقيق ايجاد شرايط مناسب براى آبيـارى

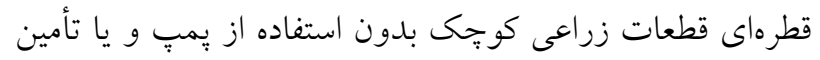

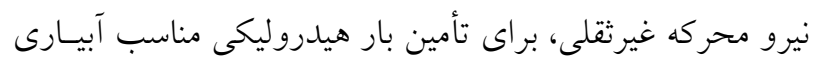
است.

\section{مواد و روشها} مواد و تجهيزات مورد استفاده

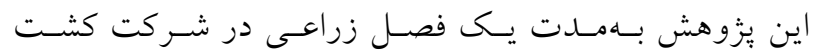
وصنعت اسفراين واقع در ب ك كيلومترى جنوب غربى شهرستان

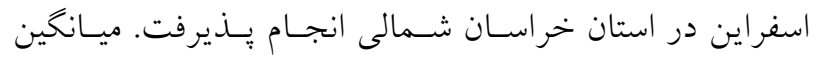

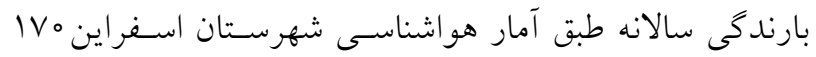

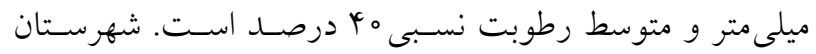
اسفراين بين Qه درجه و OV دقيقه تا ON درجه و V دقيقه طول

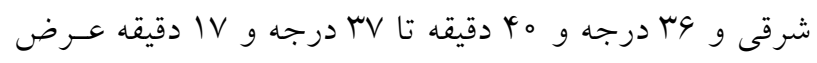

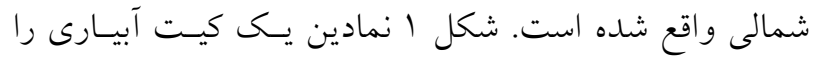
نشان مى نهد.

\section{روشها} آرايش قطرهجهانها

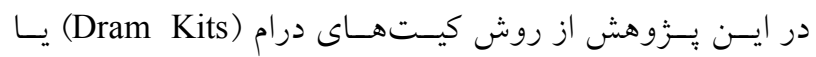

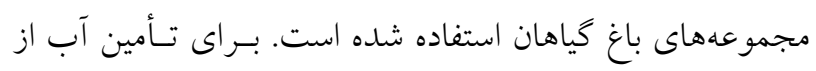

تحليل شبكه است كه مى تواند رفتار شـبكه را در همـهـ شـرايط

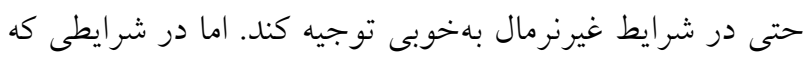

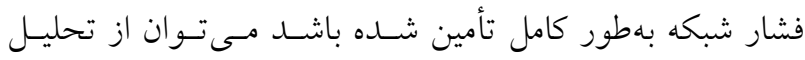

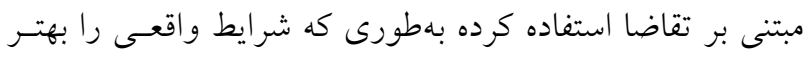

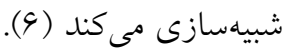
ضرورت و اهداف تحولات بعد از تصويب قانون اصلاحات ارضى در سـال بM MYT

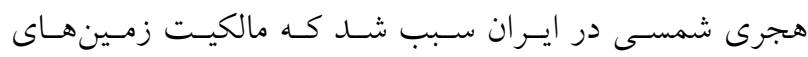
كشاورزى از مالكان كلان به كشاورزان عادى و خرده مالـكهـا انتقال يابد. اين امر موجب شد كه زمينهاى كشـاورزى از يـى

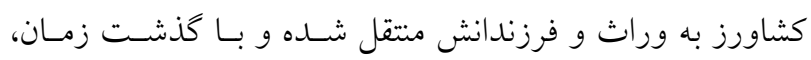

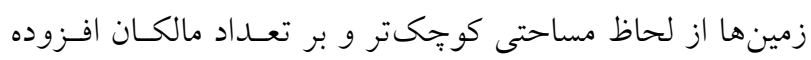

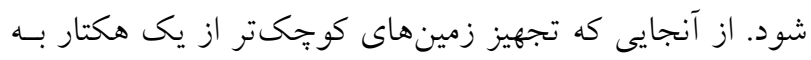

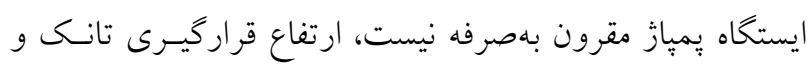

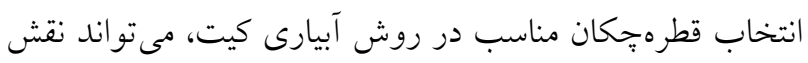

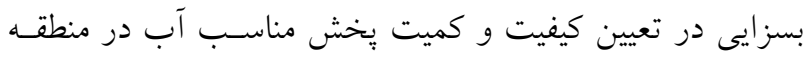
زراعى داشته باشد. با وجود بررسى ابعاد مختلف آبيـارى قطره اى در مطالعـات انجـام شــده توسط محققــان مختلـف، خـلاء

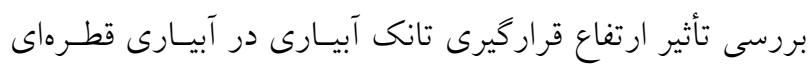

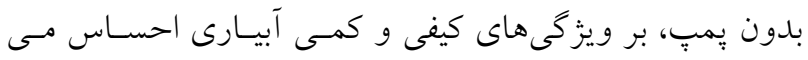




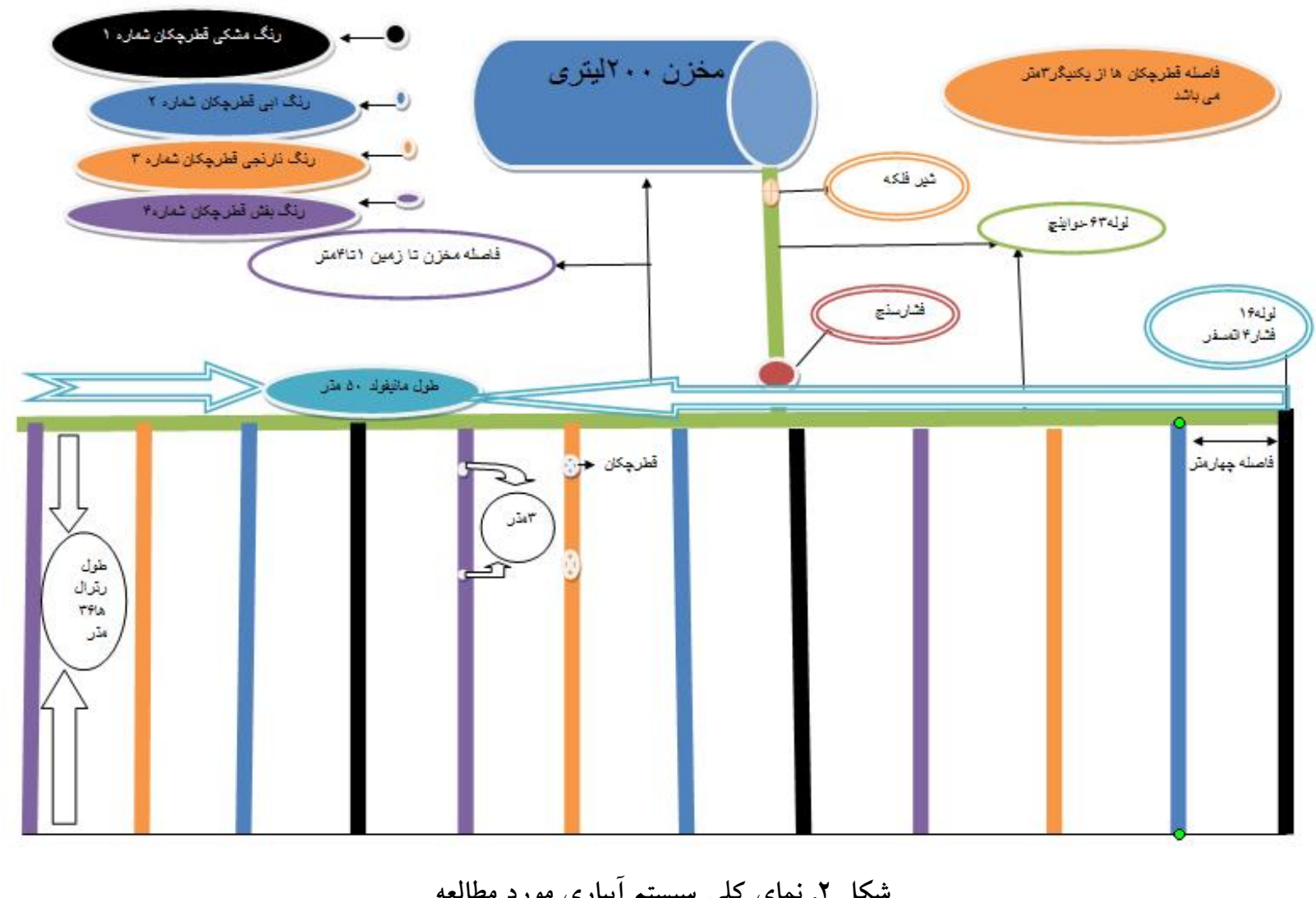

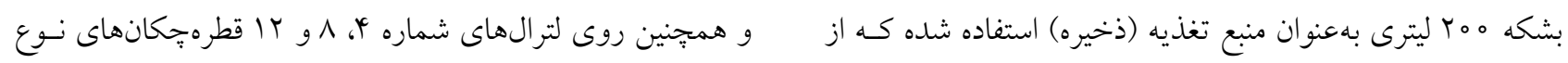

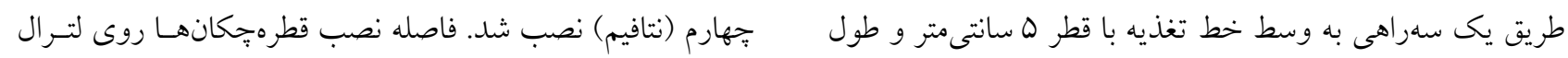

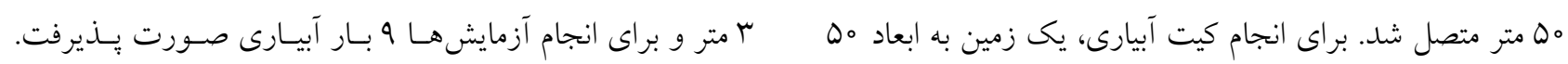

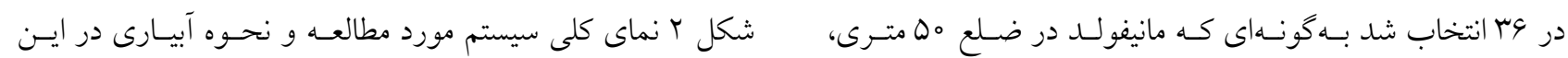

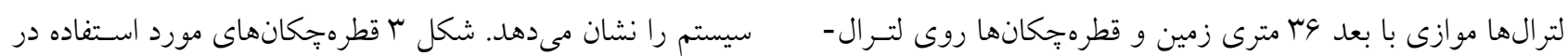

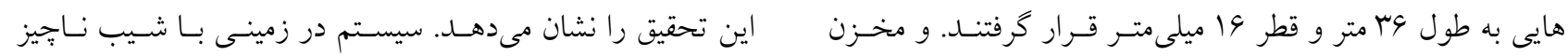

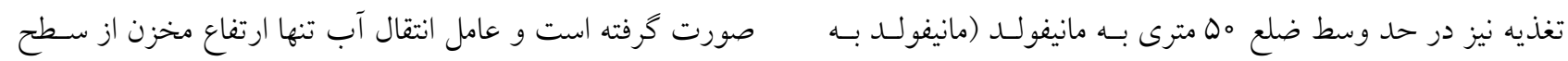

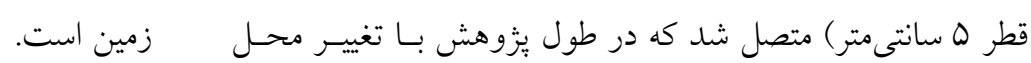

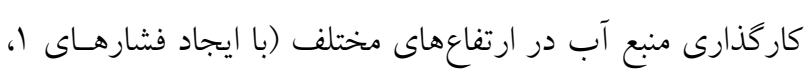

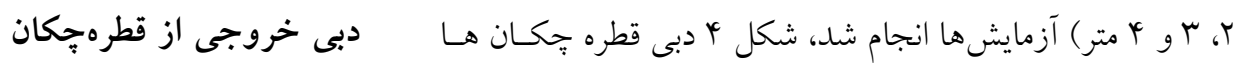

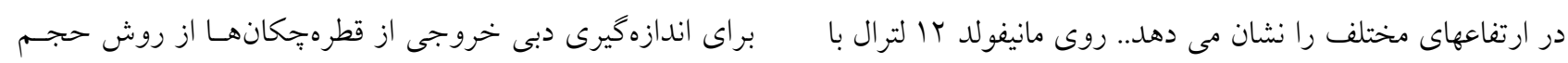

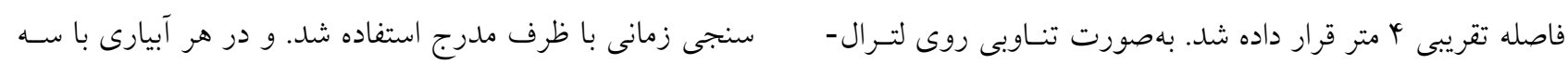

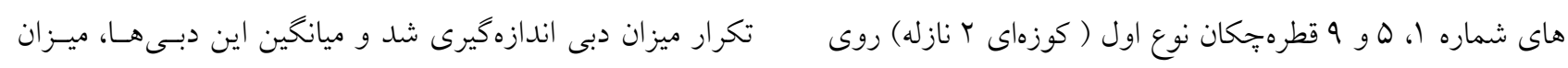

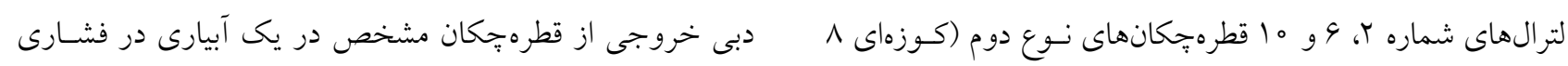

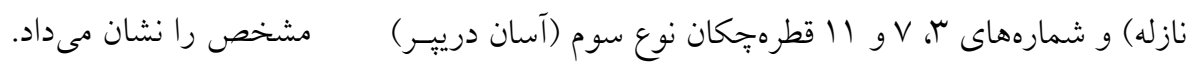




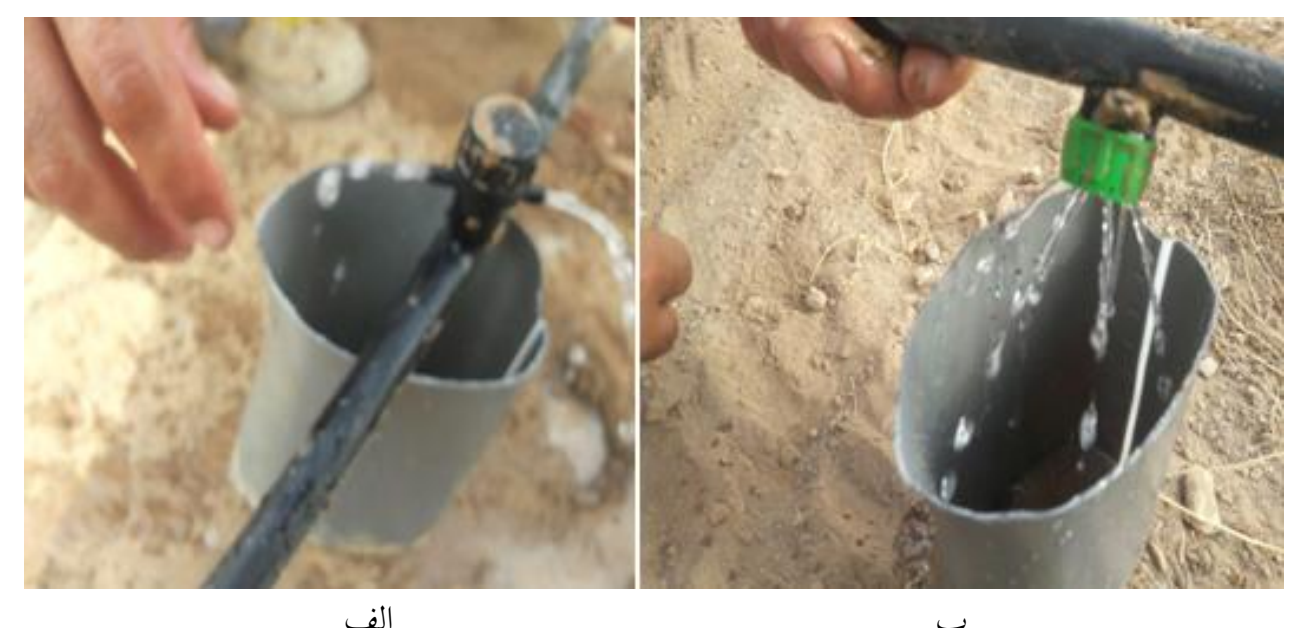

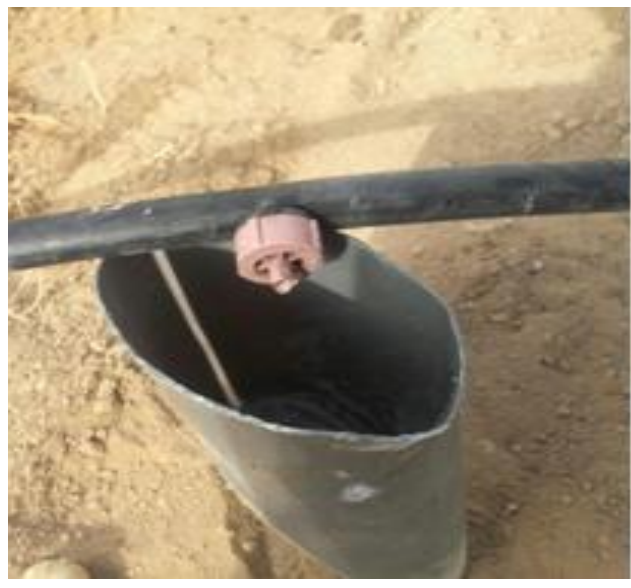

ج

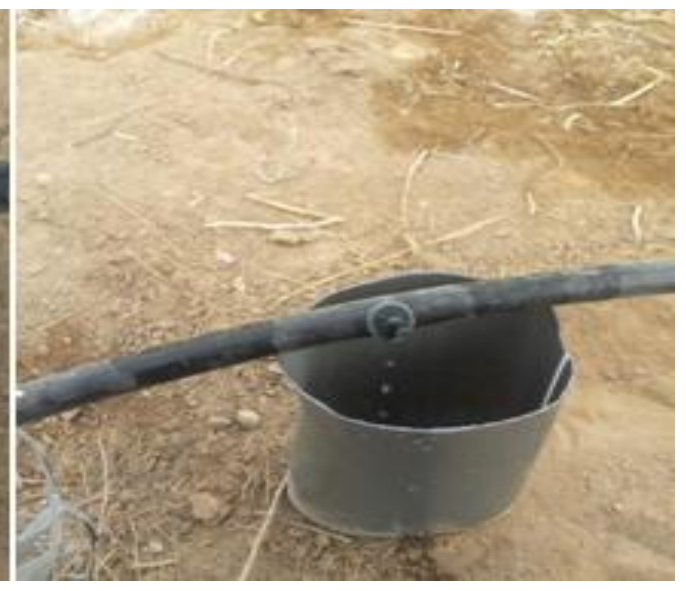

2

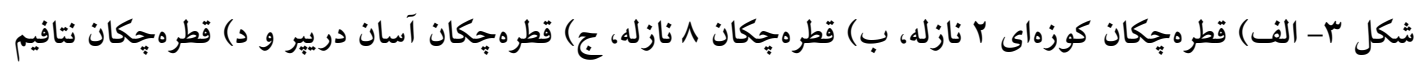

$\mathrm{A}=\mathrm{B}=\mathrm{C}=\mathrm{D}$

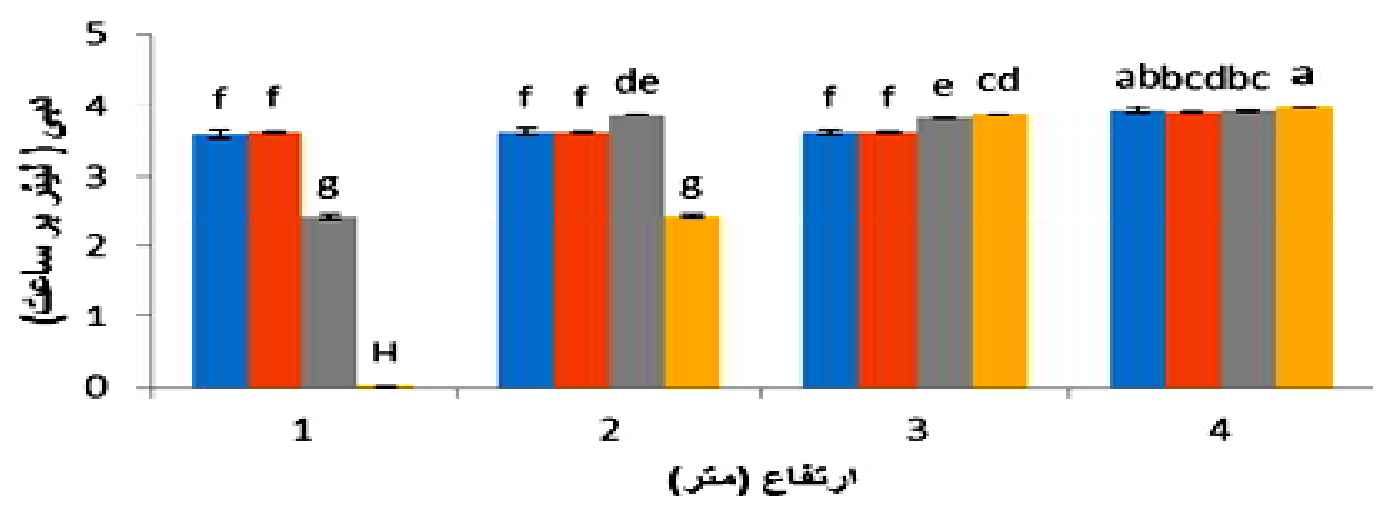

شكل f. دبى قطرهجّانها در ارتفاع نصب مخزنهاى مختلف 
سوم و جهارم) براى انـدازهيــى دو صـفت دبسى خروجسى از

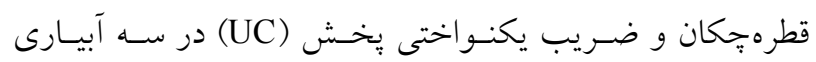

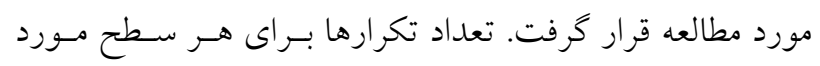

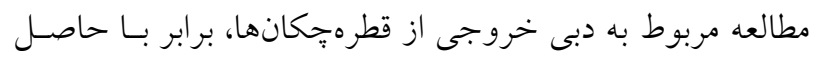

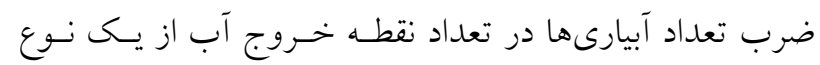

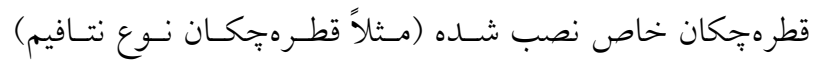

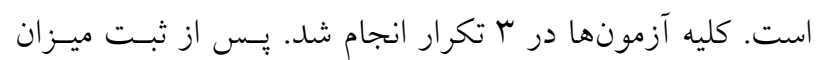

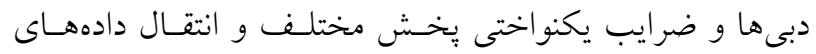

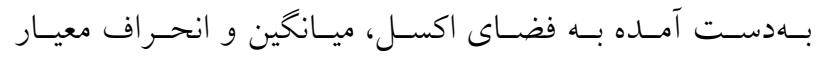
(Standard Deviation (SD)) از تيمارها و متغيرها با كاربرد آناليز واريانس يكىطرفه و استفاده

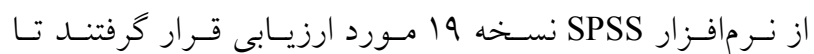
فاكتورهاى مؤثر از لحاظ آمارى شناسايى شوند. ســس مقايسـه

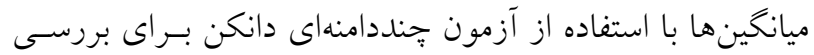
معنى دار بودن اثر متغيرها (P<o/00) انجام شد.

\section{نتايج و بحث}

تغييرات دبى قطرهجِ تهانها نسبت به ارتفاع

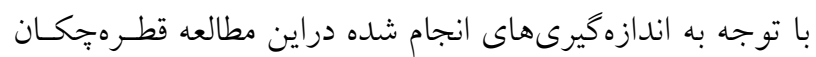

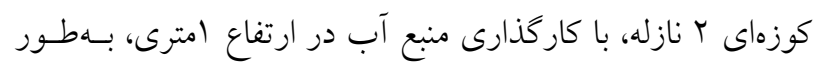

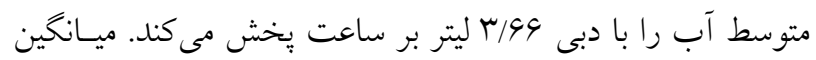

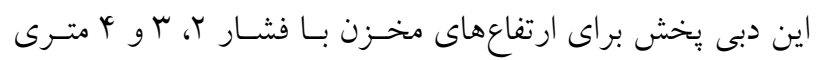

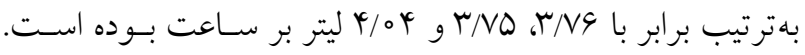

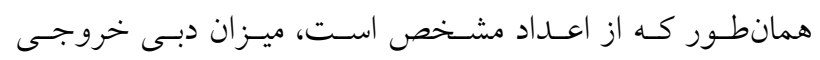

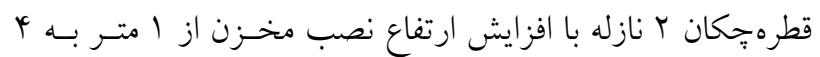

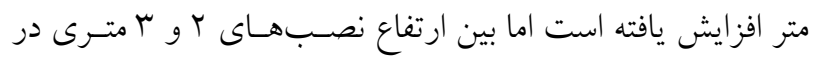

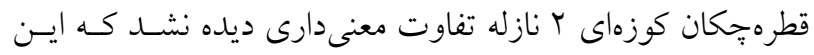

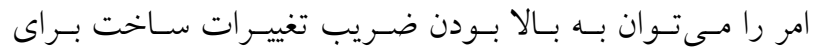
قطرهجكانهاى غير تنظيم كننده فشار نسبت داد. همجنين با نتسايج حاصل در تحقيق و عبدى و معروفيور (1) از نقطه نظر افزايش دبى با افزايش فشار و كاركرد بهنسبت مناسـب قطرهجيكـانهـاى غيرتنظيم كننده فشار در فشارهاى مختلف همخوانى داشت.

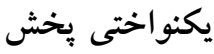

براى محاسبه ميزان يكنواختى لِخش آب در روش كيـت آبيـارى از

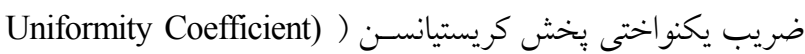

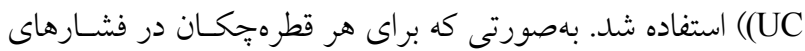

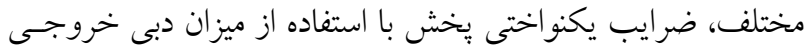

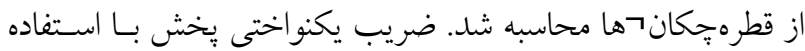
از معادله ارائه شده توسط كريستيانسن (معادله () محاسبه شد (م): $\mathrm{UC}=1-\frac{1}{\mathrm{~N}} \sum_{\mathrm{i}=1}^{\mathrm{N}} \frac{\left|\mathrm{X}_{\mathrm{i}}-\overline{\mathrm{X}}\right|}{\overline{\mathrm{X}}}$

كه در آن UC: ضـريب يكنـواختى كريستيانسـن، N: تعـداد

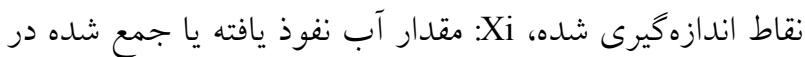

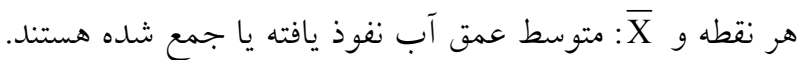

ضريب تغييرات (Coefficient of Variation) دبى يكى از بارامترهاى تكميلى كه براى تشـريح يكنـواختى بِخــش

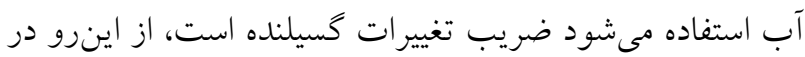
اين مطالعه علاوه بر محاسبه ضريب يكنواختى يخسـش، ضـريب

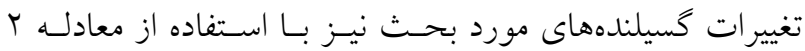

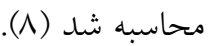

$\mathrm{Cv}=\frac{\mathrm{sd}}{\mathrm{qa}}$

كه در آن، :Cv ضريب تغييـرات سـاخت قطـرهجــان، qa:

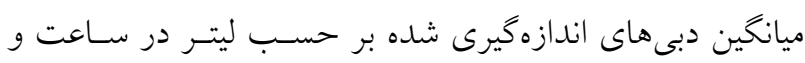

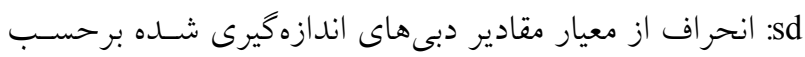

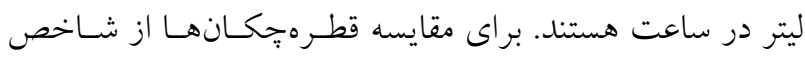

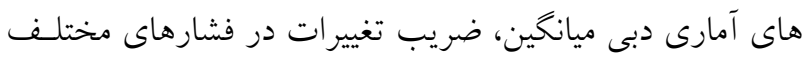

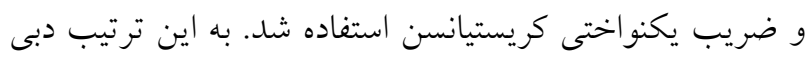

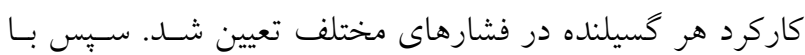

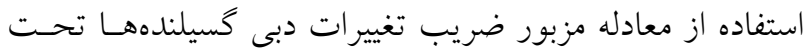

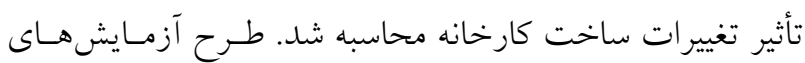

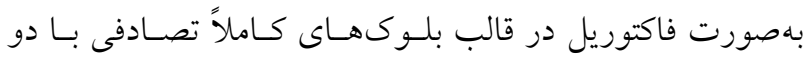

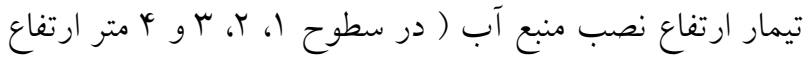
از سطح زمين) و نوع قطرهجهان (در سه سـطح نسوع اول، دوم، 


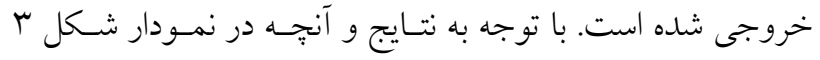

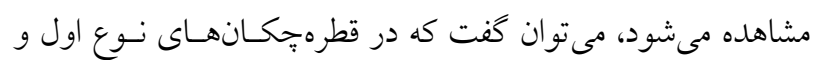

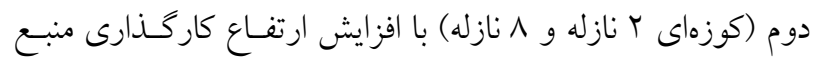
آب از ا تأ أمتر ميزان دبى خروجى قطرهجكانها همـانطسور كـهـ

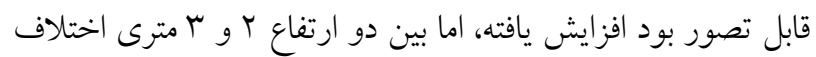

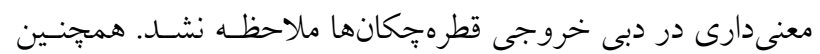

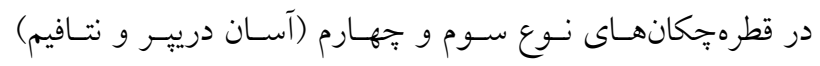

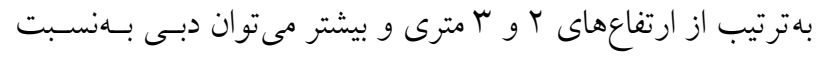

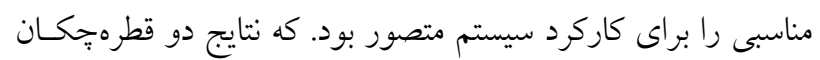

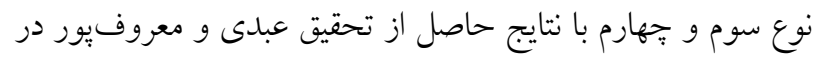
زمينه كاركرد مطلوب قطرهجكانهاى تنظيم كنده فشـار همخـوانى داشت (1). همجنين جدول اميزان خطاى استاندارد دبى هر كـدام از قطرهجكانها را در فشارهاى مختلف نشان مىدهد.

\section{ضريب تغييرات}

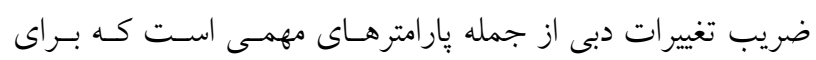

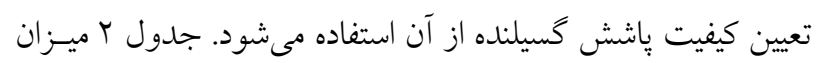

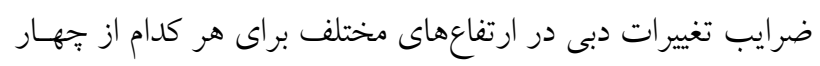

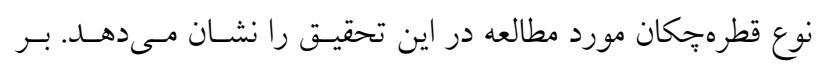

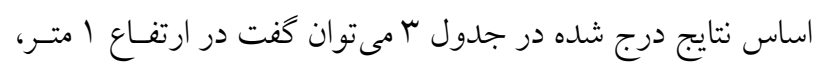

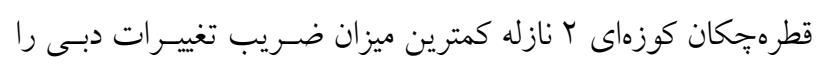

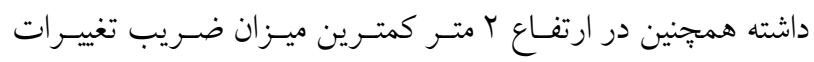

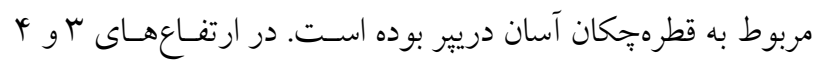

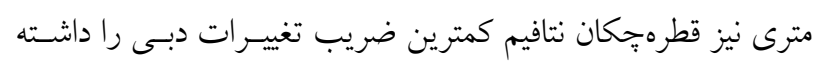
است. كه اين ميزان ضريب تغييرات مؤيد مطالب كفته شده است.

\section{يكنواختى بِخش در انواع قطرهجِكانها}

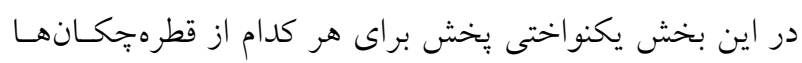

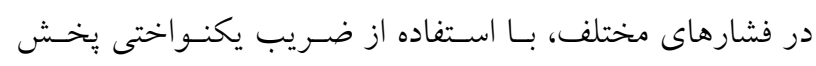

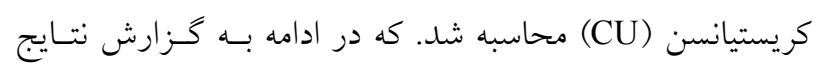

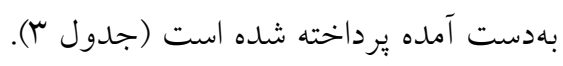

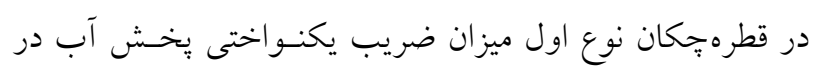

ميزان دبى يخش قطرهجهان 1 نازله در ارتفاع نصب منبع 1 مترى

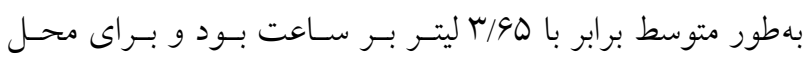

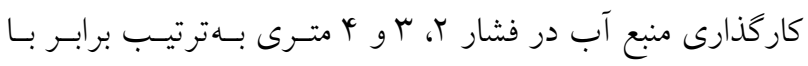

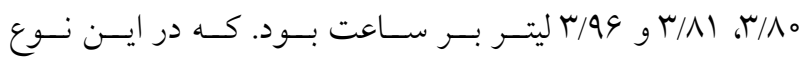

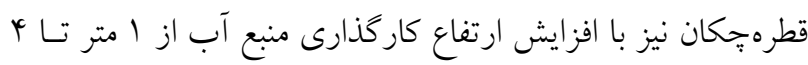

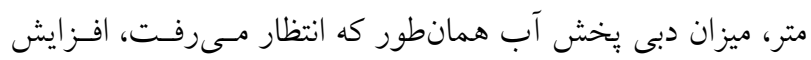

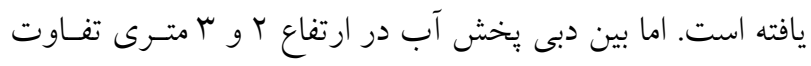
معنى دارى وجود نداشت. كه دليل اين امر را مى تـوان بـهـ اخستلال

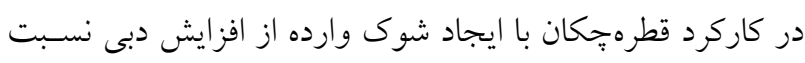

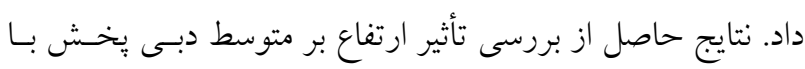

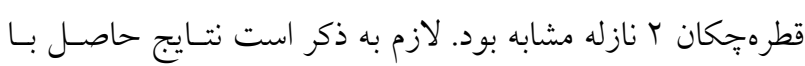

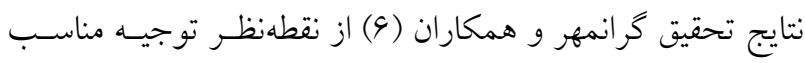

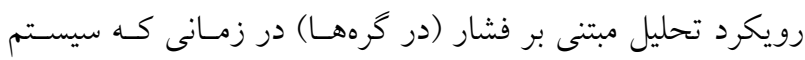

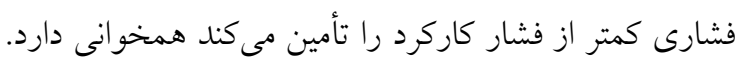

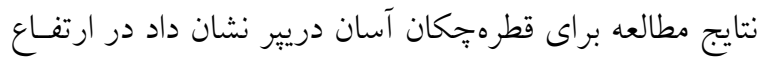

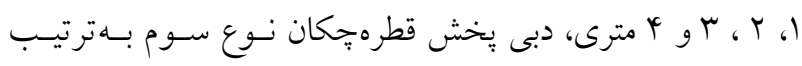

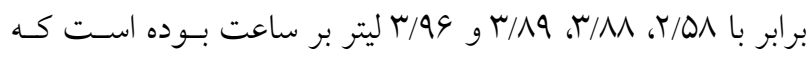

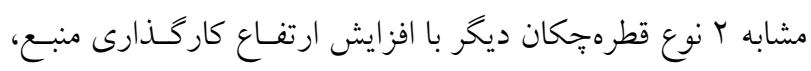

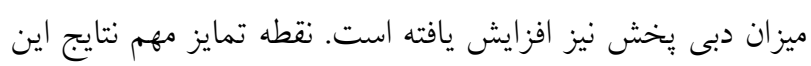

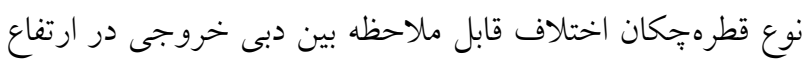

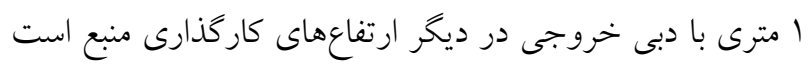

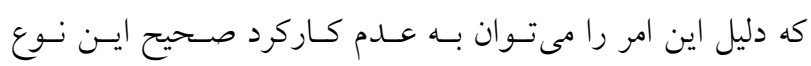

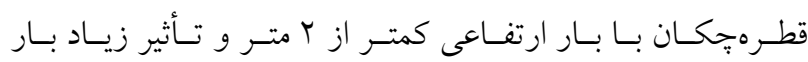

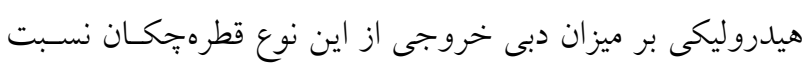

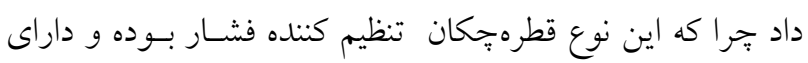
درييرهايى با قطر بزرگترى نسبت به ديخر قطرهزجانهانها هستند.

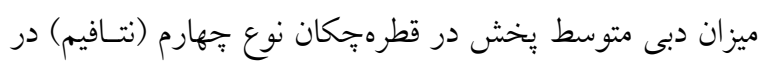

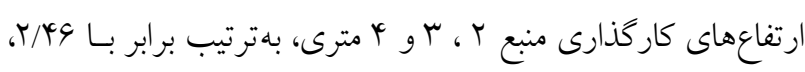

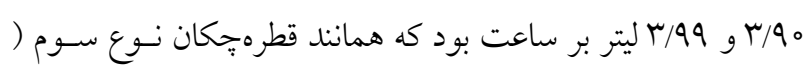

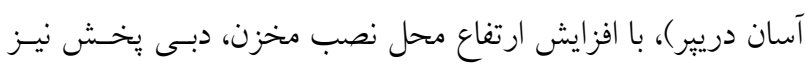

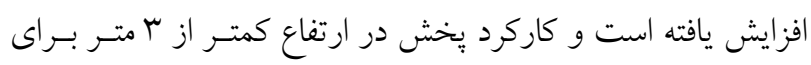

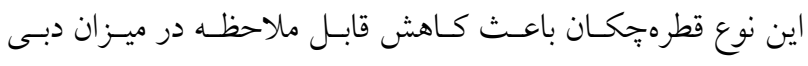


جدول ا. ميزان خطاى استاندارد دبى هر كدام از قطرهجِكانها در فشارهاى مختلف

\begin{tabular}{|c|c|c|c|c|}
\hline \multicolumn{4}{|c|}{ فشار (ارتفاع نصب منبع آب) برحسب متر } & \multirow[t]{2}{*}{ نوع قطرهجكان } \\
\hline r & $r$ & $r$ & 1 & \\
\hline \%OUYVQ &.$/ 04901$ & O/FYIKV & \%०DKVA & r نازله (A) \\
\hline.$/ 0|\wedge V V|$ & .1010011 & 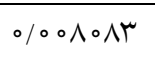 & .1010990 & 1 نازله (B) \\
\hline$\circ / 0 \circ \wedge Q Y Y$ & $\circ$ & \%००IVTr & ०/YTL०1 & آسان دريبي (C) \\
\hline 。 & 。 & /OYIOVY & - & نتافيم (D) \\
\hline
\end{tabular}

جدول r. ضريب تغييرات دبى در فشارهاى مختلف براى قطرهجإنهاى مختلف

\begin{tabular}{|c|c|c|c|c|}
\hline \multicolumn{4}{|c|}{ فشار } & \multirow{2}{*}{ نوع } \\
\hline$\varphi$ & $r$ & r & 1 & \\
\hline \%OYYV & $\circ / \circ \circ V \mu$ & GMro & .10190 & 1 \\
\hline \%VQD & O/OYYI & OOYYI & O/OITAY & r \\
\hline $0 / 0104$ & O/OYYA & $0 \% 04 q$ & \% OYAD & r \\
\hline \%०OHT &.$/ 0090$ & $\circ \% \circ V V$ & - & r \\
\hline
\end{tabular}

جدول r. ميانخين ضريب يكنواختى يخش و خطاى استاندارد انواع قطرهجِانها در فشارهاى مختلف

\begin{tabular}{|c|c|c|c|c|c|}
\hline \multicolumn{4}{|c|}{ فشار } & & \multirow{2}{*}{ نوع } \\
\hline 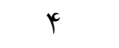 & $r$ & r & 1 & & \\
\hline $9 V / I V T$ & 99/9M & Q9/DTr & $q \wedge / \uparrow q \circ$ & ضريب يكنواختى (W) & A \\
\hline $1 / Q Y$ &.$/ 090$ & $\circ / T V q$ & $1 / 010 Y$ & خطاى استاندارد (SD) & \\
\hline $9 / / 4 \circ 1$ & $9 D / Y Y_{0}$ & $90 / 11 \circ$ & $99 / \Gamma \circ \wedge$ & ضريب يكنواختى (O) & B \\
\hline 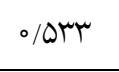 & $\circ / 0 \circ 4$ & $\circ / \mu_{1}$ & $\circ / 099$ & خطاى استاندارد (SD) & \\
\hline Q//VVY & $91 / 110$ & $99 / 4 \times 1$ & $q r / Y \circ r$ & ضريب يكنواختى (OS) & $\mathrm{C}$ \\
\hline $0 / 099$ &.$/ 09 V$ & .091 & $1 / 091$ & خطاى استاندارد (SD) & \\
\hline $99 / 4 \vee \wedge$ & $99 / \pi Y \mu$ & $9 \wedge / \vee \wedge \circ$ & - & ضريب يكنواختى (O) & \\
\hline$\circ / \circ V T$ & $\circ / \circ V \Delta$ & ०/OMI & - & خطاى استاندارد (SD) & \\
\hline
\end{tabular}


$\square \mathrm{A}=\mathrm{B}=\mathrm{C} \| \mathrm{D}$

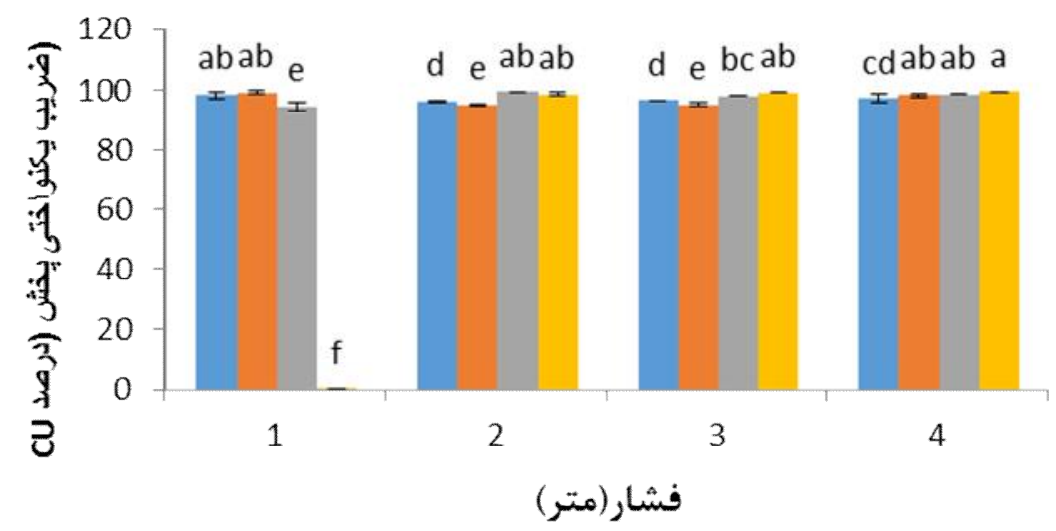

شكل ه. ضر ايب يكنواختى پِخش (UC) قطرهجِكانها در ارتفاع نصب مخزنهاى مختلف

ذكر است آناليز آمارى صورت گرفته حاكى از آن بود بين فشـار كاركردهاى r و ץ متر اختلاف معنى دارى وجود نداشت. مقادير ضرايب يكنواختى يخش آب براى قطرهجِكـان نـوع

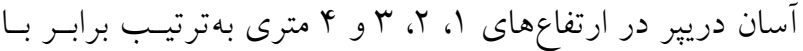
年. در قطرهجهان نوع جهارم (نتافيم) اختلاف معنسى دارى بـين ضرايب يكنواختى يخش در فشار كاركردهـاى مختلـف وجـود

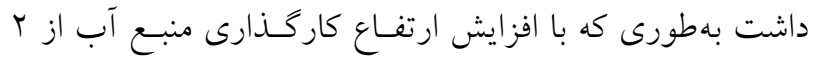

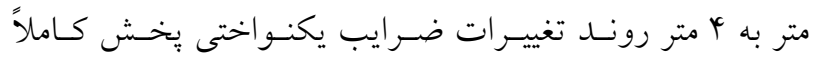

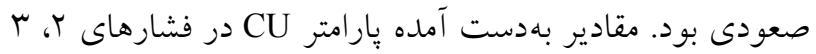

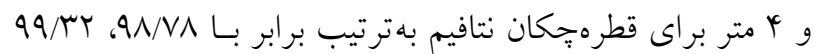

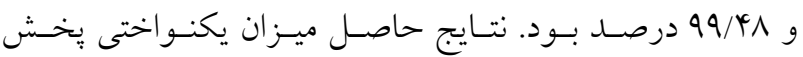
مطلوب (بيش از ه9 درصد) را در تمامى فشارها براى هر جهار

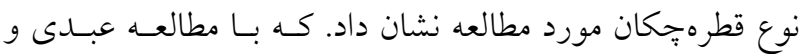
معروف يور مشابه است (1) شكل ه نمودار تغييرات ضريب يكنواختى انواع قطرهجِكانها را در فشارهاى مختلف نشان مىدهد.

انتخاب قطرهجِكان مناسب در فشار مشخص با توجه به نتايج حاصل از اندازهذيرى دبى در ارتفـاع ا متـرى،

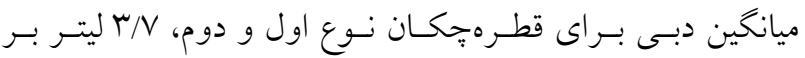
ساعت محاسبه شده است اين در حالى است كـه ميـانخين دبسى
فشار ا مترى برابر با qس/9 درصد بوده و در فشار كاركرد r، س

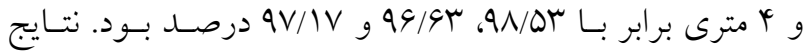
حاصل از تحليل آمارى نشان داد كه بين نصب مخزن در ارتفاع r و ب مترى اختلاف معنى دارى وجـود نداشـته و در ايسن نـوع قطرهجهان بيشترين ضريب يكنو اختى بِخش و كمتـرين درصــ خطا مربوط به كار كذارى منبـع آب در ارتفــاع ا متـر يـا همــان فشار كـاركرد ا متــر بـوده اسـت. كـهـ نتـايج حاصـل حساكى از يكنواختى يخش مناسب (بسيش از 09 درصــ) بـراى ايسن نـوع قطرهجان است.

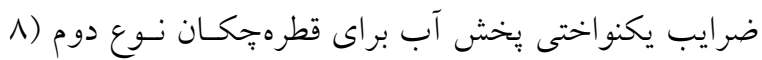

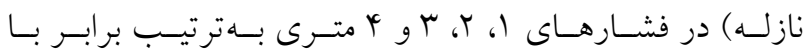
آ آناليز صورت گرفته روى مقادير بهدست آمده، بيشترين ضرايب

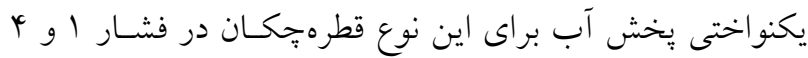
مترى اتفاق افتاده است و بين مقادير ضريب يكنـواختى ايسن دو فشار اختلاف معنى دارى وجود نداشت. همجنين بـين ضـرايب يكنواختى فشار كار كردهاى ب و ب متر نيز اخـتلاف معنسىدارى (در سطح (P > ) وجود نداشت. با توجه با اندازهيرى ميـزان ضـريب يكنـواختى بخــش در

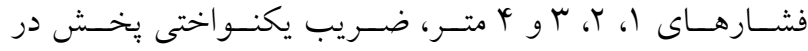
قطرهجهان نوع سوم (آسان دريبر) با افزايش ارتفــاع كاركـذارى منبع آب (فشار كاركرد) روندى تقريباً افزايشى داشـت. لازم بـه 
يكنواختى بخش دارى شرايط گسيلندگى مناسبترى است.

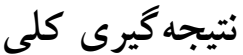

با توجه به آنجه كفته شد در شـرايط مســاوى درصـورت ثابـت

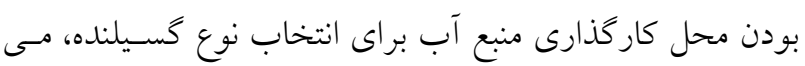
توان نتايج زير را ارائه داد:

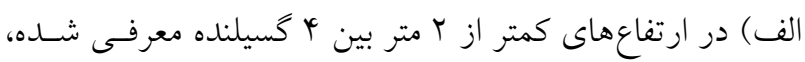
بهتر است از كسيلندهاى ץ و 1 نازله استفاده كرد.

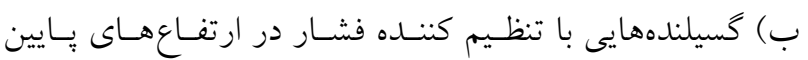
(فشار بايين) با كاهش شديد دبى روبهرو هستند.

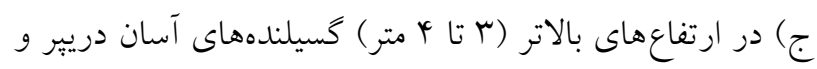

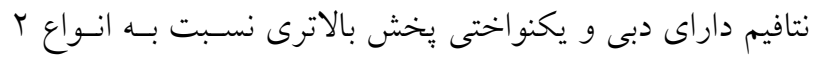

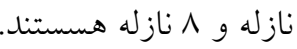
در آبيـارى قطـرهاى هرجـهـ دبسى خروجسى قطـرهجكـانهـا

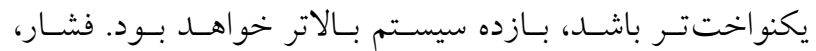

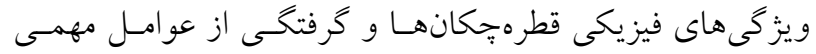

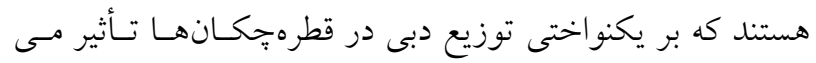

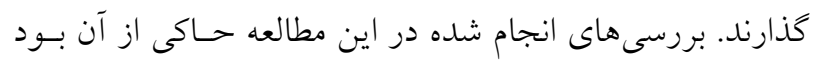

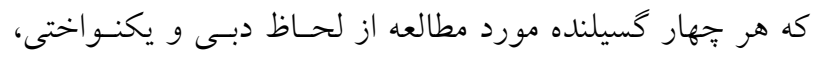

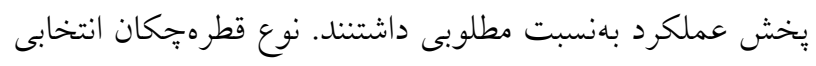

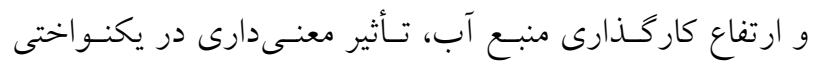

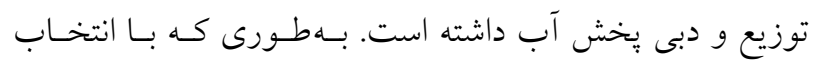

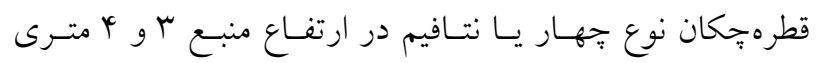

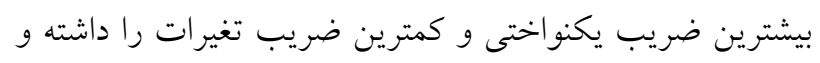

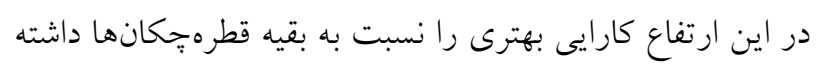

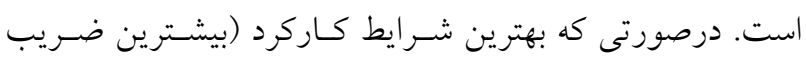

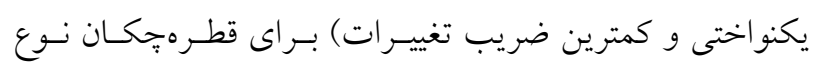

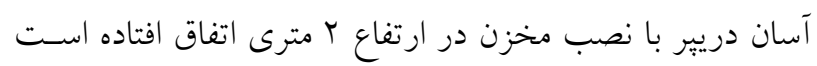

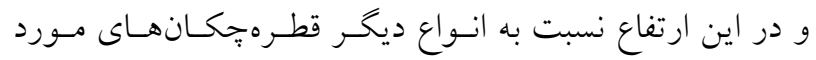

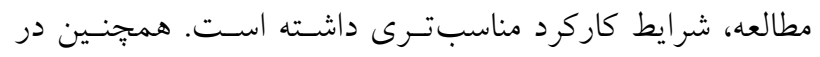

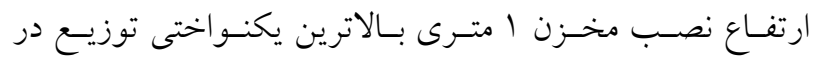

براى قطرهجهان نوع سوم (آسان درييـر )، ب/ه ليتـر بـر سـاعت

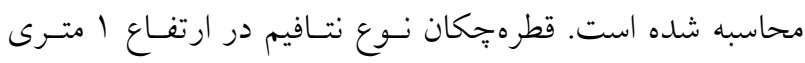

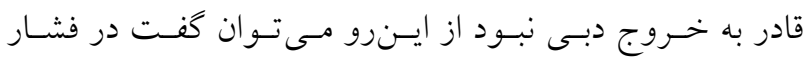

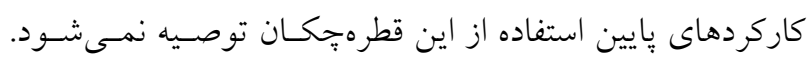

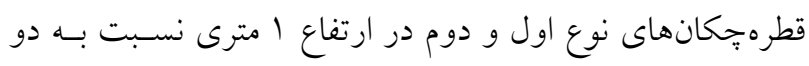
قطرهجانان نوع سوم و جهارم. دبىدهى بهترى داشتهاند. از نقطه

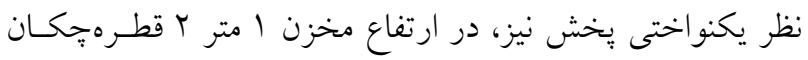

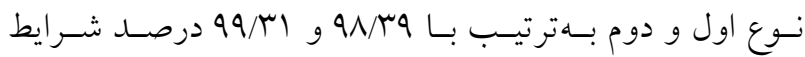

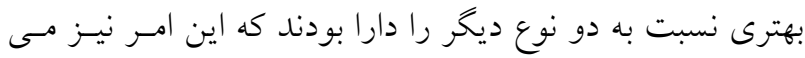

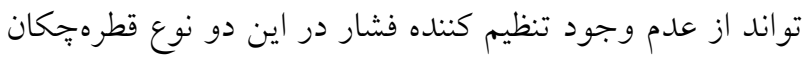
نشأت كرفته باشد. لازم به ذكر است بين ميانخين دبى و و ميانخين

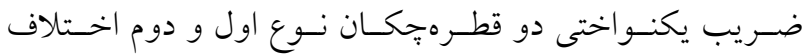

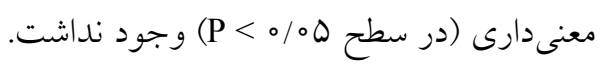

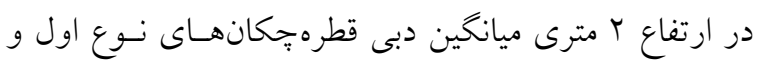

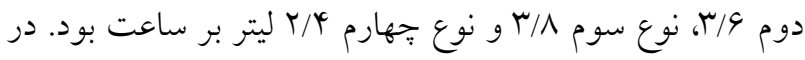

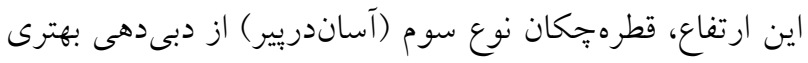

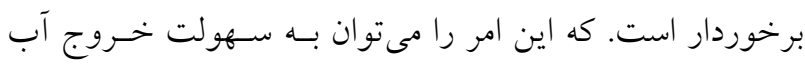

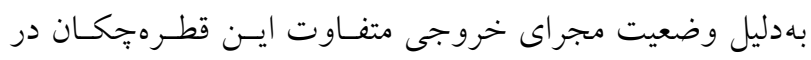
فشار كاركردهاى متوسط نسبت داد. از نقطه نظر يكنو اختى نيـز

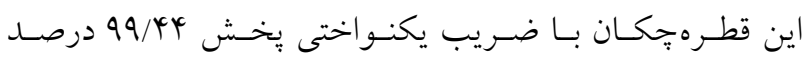
بيشترين يكنواختى وِخش را در فشار ب متر دارا بود.

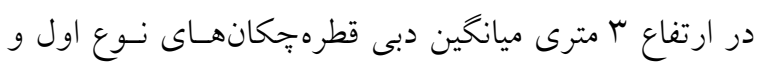
دوم

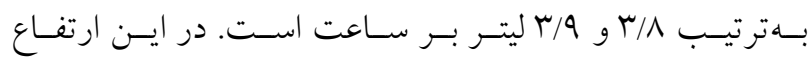

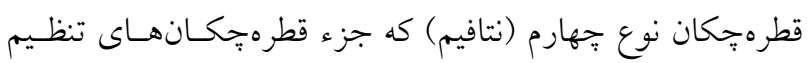

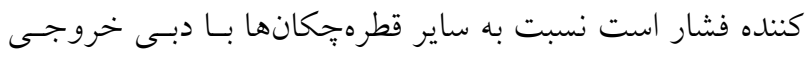

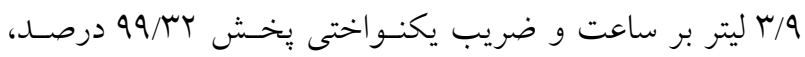

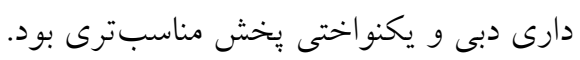

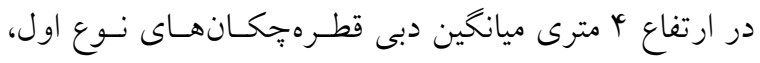

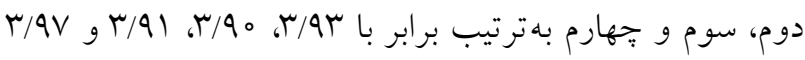

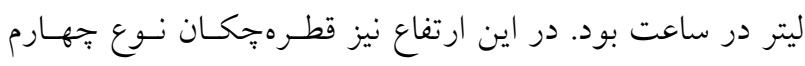

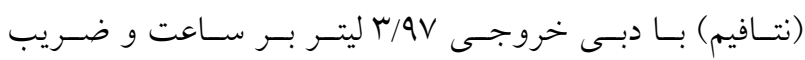




$$
\begin{aligned}
& \text { قطرهجكان نوع كوزهاى اتفاق افتاده است. درصورتى كه ارتفـاع نوع جهارم (نتافيم) كمترين ضريب تغييرات و بيشترين ضسريب } \\
& \text { كار كذارى منبع (فشار) عامل محدود كننده باشد در ارتفاع ا متر يكنواختى را داشته است. در ارتفاع ع متر قطرهجكان نوع جهـار }
\end{aligned}
$$

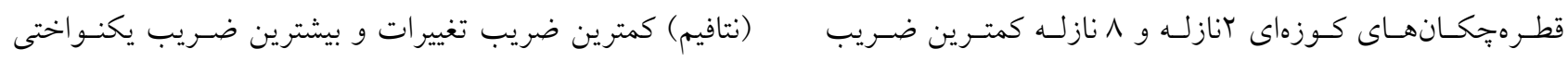

$$
\begin{aligned}
& \text { تغييرات و بيشترين يكنواختى بِخش را داشتهاند. ارتفــاع r متـر را داشته است. } \\
& \text { قطرهجهان نوع سه (آسان درييـر) كمتـرين ضـريب تغييـرات و } \\
& \text { بيشترين ضريب يكنواختى داشته است. ارتفاع بم متر قطرهِّكان }
\end{aligned}
$$

\section{منابع مورد استفاده}

1. Abdi, S. and A. Maroofpour. 2016. Investigation of the relationship between flow-pressure and flow-temperature in the self-regulating and non-regular regulation of the droplet droplet tubes in the country, Water and soil conservation studies. Journal of Water and Soil Conservation 23(1): 233-245. (In Farsi).

2. Abedi Koupai, J. and A. Bakhtiari Far. 2004. Effect of wastewater treatment on hydraulic properties of drip irrigation system. Journal of Water and Soil Sciences 8(3): 33-42. (In Farsi).

3. Arab Fard, M., A. Shahnazari and M. Ziyatbar Ahmadi. 2016. Comparison of the Efficiency of Coase Irrigation Methods, Grain Diameters and Permafrost in Grain Pressure Range. Journal of Water and Soil (Agricultural Science and Technology) 31(4): 1060-1069. (In Farsi).

4. Ditto, W. L., A. Miliotis, K. Murali, S. Sinha and M. L. Spano. 2010. Chaogates: Morphing logic gates that exploit dynamical patterns. Chaos: An Interdisciplinary Journal of Nonlinear Science 20: 127-137

5. Gassim, A. 2003. Micro-irrigation: A situation analysis: institute of sustainable irrigated agriculture (ISIA) at Tatura. Australia, for the International Program for Technology \& Research Irrigation \& Drainage (IPTRID).

6. Granmehr, M. A., M. R. Chamani and K. Asghari. 2016. Pressure-based analysis in water distribution networks using particle swarm optimization algorithm. Journal of Water and Soil Sciences (Science and Technology of Agriculture and Natural Resources) 22(3): 23-39. (In Farsi).

7. Hezarjaribi, A., Gh. Ghorbani Nasr Abad, R. Fazlollahi and M. Abedinpour. 2013. Investigating the hydraulic performance of three types of exterior adjusting droplets in different operating pressures. Journal of Water and Soil Conservation 20(2): 199. (In Farsi).

8. Keller, J. and D. Karmeli. 1975. Trickle Irrigation Design. Glendora, California: Rain Bird Sprinkler Manufacuring Crop.

9. Koushki, P. A., M. A. Bustan and N. Kartam. 2003. Impact of safety belt use on road accident injury and injury type in Kuwait. Accident Analysis \& Prevention 35: 237-241.

10. Malaee, M. S., A. Mahdi and A. R. Vatankhah. 2012. Laboratory study of hydraulic characteristics of irrigation systems for low pressure dams. Iranian Journal of Soil and Water Research 45(1): 37-45. (In Farsi).

11. Pasternak, D., A. Nikiema, D. Senbeto, F. Dougbedji and L. Woltering. 2006. Intensification and improvement of market gardening in the Sudano-Sahel Region of Africa. Chronica Horticulturae 46: 87-101. 


\title{
Investigating the Effect of Pressure on Water Leakage by Drip Irrigation without a Pump in Four Different Ejectors
}

\author{
M. Khast, M. Hesam*, A. Hezarjaribi and O. Mohamadi ${ }^{1}$
}

(Received: Desember 18-2018 ; Accepted: July 28-2019)

\begin{abstract}
Due to the increasing number of small crops, the system of irrigation without a pump can be an economical way. Therefore, in this research, the effects of the type of droplet and the height of water supply system utilization on the characteristics of water distribution (discharge, dispersion uniformity coefficient (CU) and coefficients of variation of discharge) were investigated. In this research, the pressure functions of 1, 2, 3 and 4 meters and three irrigation repeats were investigated; also, the discharge characteristics of jet pots of 2 and 8 nozzles, easy dripper and netafim were addressed. The results indicated that at $1 \mathrm{~m}$ pressure, drippers of pots of 2 and 8 nozzles with the uniformity coefficients of distribution were equal to 89.39 and $99.30 \%$, and the discharge rate was 3.60 and 3.62 liters per hour at a pressure of $2 \mathrm{~m}$. An easy-drain drip with a discharge rate of $3.85 \mathrm{~L} / \mathrm{h}$ and a uniform distribution of $99.44 \%$, at a height of 3 and 4 $\mathrm{m}$, the droplets of the netafim with an outlet discharge were 3.87 and 3.97 liters per hour and the uniformity coefficients of 99.32 and 99.47 percent had the best broadcast conditions. According to these significant differences $(P<0.05)$, it can be concluded that at pressures less than $2 \mathrm{~m}$ of jar droplets and at more than $3 \mathrm{~m}$, netafim and Easy Dipper types could have better leakage due to pressure regulators. In general, each of the four types of emitters produced a uniform dispersion and the optimum discharge at different pressures.
\end{abstract}

Keywords: Irrigation kit, Drip irrigation, Discharge, Uniformity factor

1- Department of Irrigation and Drainage, Gorgan University of Agricultural Sciences and Natural Resources,Gorgan, Iran.

*: Corresponding author, Email: mhesam@yahoo.com 